\title{
Podstawy edukacji ignacjańskiej, Wydawnictwo WAM, Kraków 2006, ss. 175
}

Powstanie, jak również działalność Towarzystwa Jezusowego były bez wątpienia przełomem w dziedzinie edukacji. Założyciel zakonu św. Ignacy Loyola oraz jego współbracia pragnęli nie tylko pogłębiać wiarę, lecz także kształtować młodych ludzi o jasnych umysłach i otwartych sercach, gotowych zmieniać swoje życie na lepsze. Jezuici postawili przed sobą cel tyleż wzniosły, co trudny. Jednakże pomimo wielu momentów dla zakonu trudnych, takich jak początkowa niechęć dla ich edukacji, problemów natury materialnej, czy wreszcie kasaty zakonu decyzją papieża Klemensa XIV w 1773 r., wreszcie burzliwego wieku XX wraz z II wojną światową, ich starania nie poszły na marne, a wkład do nauki i kultury jest dyskusyjny.

Książka Podstawy edukacji ignacjańskiej jest publikacją wydaną przez Wydawnictwo WAM w 2006 r., pod redakcją Jakuba Kołacza SJ. Jest to przekład dzieła pt. The Characteristics of Jesuit Education, Acta Romana Societatis Jesu, Roma 1986, dokonany przez Bogusława Steczka SJ. Jest to próba ukazania wizji pedagogiki św. Ignacego Loyoli, a powstała w odpowiedzi na pytanie o skuteczność jezuickich szkół i jezuickiego przesłania aktualności. Zawiera ona wszystkie najważniejsze idee i założenia edukacji według jezuitów. Problem skuteczności pedagogiki ignacjańskiej pojawił się na spotkaniu międzynarodowej grupy osób świeckich oraz jezuitów w Rzymie, w 1980 r. Podejmowano tam temat zarówno efektywności edukacji ignacjańskiej, jak i zastanawiano się, w jakim stopniu stanowi ona narzędzie służące osiąganiu celów zakonu oraz to, jaka będzie jej przyszłość.

Wydawnictwo to, poświęcone jezuickiemu dziedzictwu, zawiera najistotniejsze i najbardziej charakterystyczne cechy wychowania według św. Ignacego, a także ukazuje relacje miedzy elementami jezuickiego systemu wychowania a wizją założyciela zakonu. Publikacja, poświęcona szczególnemu charakterowi jezuickiej działalności wychowawczej i edukacyjnej, adresowana jest, jak piszą sami autorzy, do jezuitów i osób świeckich, którzy mają na co dzień do czynienia z młodymi ludźmi w jezuickich ośrodkach wychowawczych. Książka przeznaczona jest zatem zarówno dla nauczycieli, pracowników administracji, rodziców, jak i zarządu tych ośrodków.

Wydawnictwo to składa się z części teoretycznej oraz praktycznego podejścia pedagogiki ignacjańskiej. Na strukturę pracy składa się opis dwudziestu ośmiu podstawowych cech tegoż wychowania, ze szczególnym uwzględnieniem edukacji w szkołach i kolegiach. I tak rozdział pierwszy - „Bóg” (s. 19-23), traktujący o Bogu, dotyka sprawy afirmacji rzeczywistości świata, mówi o sensie ludzkiego życia, wskazuje na istotną rolę zarówno nauk humanistycznych, jak i przyrodniczych oraz wartości wychowania fizycznego. Podkreśla rolę sfery uczuć i wyobraźni, a także uczula na zrozumienie i krytyczny odbiór środków masowego przekazu, tak bardzo obecnych w otaczającym nas świecie. W następnej kolejności, w rozdziale pt. „Wolność człowieka” (s. 25-27), poruszona jest kwesta religijnego wymiaru wychowania, czy dialogu między wiarą a kulturą. Pedagogika ignacjańska to także wolność człowieka, zwrócenie się ku jego sprawom oraz głęboka troska o niego. Rozdział trzeci „W poszukiwaniu wolności” (s. 28-30) - następna ważna kwestia w publikacji - a w niej waga poznania, miłości i akceptacji samego siebie. Kolejny rozdział tego wydawnictwa - „Chrystus - wzór osoby” (s. 32-34) - traktuje o osobie 
Chrystusa jako o wzorze ludzkiego życia. Wskazuje na duszpasterską troskę, która umożliwia przede wszystkim dostrzeżenie Boga w całym stworzeniu. Pojawia się także element ćwiczeń duchownych mających na celu dotarcie do Chrystusa, poznanie oraz pokochanie Go. Jezuici nie zapomnieli także o czynnym zaangażowaniu w życie. W „Działaniu” (s. 36-40) - piątym rozdziale - odpowiadają na pytania: Jak ważne jest działanie?, Czym jest budowanie pokoju?, Dlaczego warto służyć wierze i szerzyć sprawiedliwość?. Ważne miejsce w rozważaniach zajmuje także Kościół, stąd kolejny, szósty rozdział pt. „W kościele” (s. 42-44). Dla jezuitów, szerzących wiarę i pobożność, ważne było przygotowanie uczniów do aktywnego uczestnictwa w życiu Kościoła. Pojawia się więc pojęcie służby Kościołowi, wierności czy więzi z Kościołem. „Magis” (s. 46-48) czyli więcej, bardziej, najpełniej - to następny w kolejności rozdział oraz ważny punkt pedagogiki jezuickiej. To przede wszystkim chęć jeszcze większego, lepszego poznania Boga także poprzez własny rozwój, wierne oddanie się Bogu oraz gorliwa praca apostolska. Ważnym elementem jest bez wątpienia „Wspólnota” (s. 49-54). Rozważania dotyczące wspólnoty znalazły swoje miejsce w ósmym rozdziale. Wyraża się ona przez współpracę jezuitów i osób świeckich, a nie może istnieć bez ducha wspólnoty pośród tych, którzy pragną w niej uczestniczyć. Ostatnim rozdziałem a zarazem ważnym punktem jest „Rozeznanie” (s. 57-59), czyli adaptacja w celu osiągnięcia postawionych pedagogice ignacjańskiej zadań. To stała refleksja i ocena, dobór odpowiednich środków, wymiana doświadczeń na polu edukacji między szkołami, a także współpraca nauczycieli.

Książka sięga także do historii życia św. Ignacego, początków działalności Towarzystwa Jezusowego, oraz omawia Ratio Studiorum - Ustawę Szkolną Towarzystwa Jezusowego, powstałą w 1599 r., a zawierającą szczegółowe zasady regulujące działalnością zakonu w zakresie edukacji. Informacje te mają szczególne znaczenie dla tych czytelników, którzy z osobą św. Ignacego Loyoli oraz samym zakonem i jego działalnością edukacyjną nie mieli okazji się zetknąć, lub też zetknęli się w sposób niewystarczający. Książka zawiera także podejście praktyczne do pedagogiki ignacjańskiej. W podejściu tym zawarty jest przede wszystkim cel wychowania według jezuitów, a więc osiągnięcie przez uczniów pełnego rozwoju intelektualnego, który prowadzi do działania nacechowanego obecnością Chrystusa i kierowanie się zawsze Jego zasadami. Podejście praktyczne to także "Ćwiczenia duchowne" autorstwa Św. Ignacego, które mają na celu spotkanie żywego Boga poprzez modlitwę, a także poznanie prawdy i pomoc w podejmowaniu ważnych, życiowych wyborów. Nie bez komentarza pozostawili jezuici również relację uczeń-nauczyciel. W relacji tej nauczyciel powinien umożliwiać uczniowi poznanie prawdy i dotarcie do Boga w taki sposób, aby uczeń pragnął wyjść poza sferę poznania i chciał podjąć dalsze działania.

Publikacja nie ucieka od spraw trudnych, poruszając kwestię trudności w stosowaniu pedagogiki ignacjańskiej. Pojawia się tutaj problem ograniczonej perspektywy wychowania, przewagi pragmatyzmu, chęci stosowania prostych rozwiązań, poczucia niepewności, czy też problemu obowiązujących rządowych programów nauczania. Autorzy nie zostawiają jednak czytelnika bez ukazania praktycznych porad i pomocy w zrozumieniu modelu pedagogiki ignacjańskiej, a także zapraszają do współpracy nauczycieli, którzy chcieliby zaproponować ciekawe rozwiązania przy opracowywaniu lekcji z zastosowaniem modelu edukacji według jezuitów. 
Autorzy tego wydawnictwa, zdając sobie sprawę z ogromnej wartości dokonań Towarzystwa Jezusowego na polu oświaty i wychowania, zapraszają do lektury wszystkich tych, którzy pragną realizować wizję św. Ignacego, kontynuować szlachetną tradycję, korzystać $\mathrm{z}$ bezcennych dokonań zakonu, a także przystosowywać model pedagogiki ignacjańskiej do obecnych czasów i torować jej drogę na przyszłość.

Joanna Falkowska

Karol Poznański, Wybrane zagadnienia $z$ historii wychowania. $C z$. 2, Warszawa 2006, Wydawnictwo Akademii Pedagogiki Specjalnej im. Marii Grzegorzewskiej w Warszawie, ss. 247

W ostatnich latach pojawiło się kilka nowych wydawnictw podręcznikowych do historii wychowania. Są wśród nich zarówno opracowania o charakterze syntez, jak i zarysów czy skryptów. Warto wśród nich wymienić Zarys historii wychowania Kaliny Bartnickiej i Ireny Szybiak ${ }^{1}$ oraz wydany w 2004 r., nakładem wydawnictwa WAM w Krakowie, podręcznik akademicki Historia wychowania. Do Wielkiej Rewolucji Francuskiej autorstwa Stanisława Litaka, uzupełniony w rok później tomem II pt. Historia wychowania. Wiek XIX $i$ XX, którego opracowania podjęli się Jan Draus i Ryszard Terlecki. Rok 2006 przyniósł wznowienie podręczników Stefana Możdżenia ${ }^{2}$ oraz dwa nowe opracowania pomocnicze - Historię wychowania. Skrypt dla studentów pedagogiki pod redakcją Danuty Dryndy ${ }^{3}$ oraz Wybrane zagadnienia z historii wychowania, cz. II opracowane przez Karola Poznańskiego. Ostatnia z wymienionych publikacji stanowi kontynuację wydanych w 2001 r., również przez Wydawnictwo Akademii Pedagogiki Specjalnej im. Marii Grzegorzewskiej w Warszawie, Wybranych zagadnien z historii wychowania cz. 1, autorstwa Hanny Markiewiczowej. Część I objęła okres od starożytności do reformacji i kontrreformacji, natomiast Karol Poznański w swojej książce uwzględnił dzieje wychowania od czasów nowożytnych do początków wieku XX (okres II Rzeczypospolitej).

Profesor Karol Poznański ukończył studia pedagogiczne na Katolickim Uniwersytecie Lubelskim, gdzie pod wpływem i opieką naukową prof. Jana Dobrzańskiego, napisał pracę magisterską i doktorską $\mathrm{z}$ zakresu historii wychowania. Habilitował się $\mathrm{w}$ roku 1972, w 1991 r. uzyskał tytuł profesora zwyczajnego. Od wielu lat prowadzi zajęcia z za-

\footnotetext{
${ }^{1}$ K. Bartnicka, I. Szybiak, Zarys historii wychowania, Wydawnictwo Akademickie „Żak” i Wyższa Szkoła Humanistyczna w Pułtusku, Warszawa 2001, ss. 221.

${ }^{2}$ S. Możdżeń, Historia wychowania do 1795 roku, Sandomierz 2006, ss. 431; idem, Historia wychowania 1795-1918, Sandomierz 2006, ss. 397; Historia wychowania 1918-1945, Sandomierz 2006, ss. 275.

${ }^{3}$ Historia wychowania. Skrypt dla studentów pedagogiki, pod red. D. Dryndy, Wydawnictwo Wyższej Szkoły Pedagogicznej TWP, Warszawa 2006, ss. 234.
} 